\author{
식물성유 첨가가 면양의 반추위 발효특성과 소화율 및 지방산염 \\ 형성에 미치는 영향 \\ 김동일* · 최정락* · 조석현** . 이도형*** . 정태영* \\ 건국대학교 축산학과*, (주)CTC바이오**, 드림피드텍***
}

\title{
Effects of Supplemental Vegetable Oils on Ruminal Characteristics, Digestibility and Formation of Fatty Acid Soaps in Sheep
}

\author{
D. I. Kim*, J. R. Choi*, S. H. Cho**, D. H. Lee*** and T. Y. Chung*
}

Department of Animal Science, Konkuk University*, CTCBIO INC.**, Dream Feed Tech.***

\begin{abstract}
This experiment were conducted to determine the formation of fatty acid soaps, digestibility and ruminal characteristics when vegetable oils were added. Three Corriedale×Suffolk sheep fitted with rumen cannula were used in a $3 \times 3$ Latin square design. Sheep were fed one of three diets consisting of alfalfa hay and concentrates in a ratio of $70: 30$. Dietary treatments were 1) no oil, 2) 7\% soybean oil and 3) $7 \%$ corn oil. At the end of each experimental period, rumen contents from each sheep were collected before feeding and at 1, 3, 6 and $9 \mathrm{~h}$ after feeding. $\mathrm{pH}$ decreased up to the 3 hour after feeding and increased until the end of the collection $(\mathrm{P}<0.0001)$. Whereas the concentration of $\mathrm{NH}_{3}-\mathrm{N}$ showed inverse changes to $\mathrm{pH}(\mathrm{P}<0.0001)$. Type of oil did not affect the molar concentration of total VFA, acetate, propionate and butyrate. Acetic/propionic acid $(\mathrm{A} / \mathrm{P})$ ratio decreased with increasing time $(\mathrm{P}<0.0001)$, but the ratio at the end of the experiment became similar to the initial value. No effects were found in the digestibility of dry matter, total-N, crude fiber, ash, NFE, NDF and ADF. The formation of fatty acid soaps(FAS) increased after feeding than 1 hour before feeding $(\mathrm{P}<0.05)$ and increased in $7 \%$ oils than no oil addition $(\mathrm{P}<0.05)$. Long chain fatty acids formed mainly FAS. Since the formation of FAS might decrease negative effects on ruminal characteristics and total tract digestibility.

(Key words : Vegetable oil, Fatty acid soaps, Ruminal characteristics, Digestibility)
\end{abstract}

$$
\text { I 서 론 }
$$

일반적으로 반추동물 사료에는 총 지방함량 이 $2 \sim 5 \%$ 이고, 이중 지방산은 $1 \sim 2.5 \%$ 정도이 다(Tamminga와 Doreau, 1991). 실제 사양에 있 어서 건물 기준으로 사료의 지방함량이 $5 \%$ 를 넘게 되면 반추위내 조섬유 소화가 저하되고, $7 \sim 8 \%$ 이상이면 반추위 미생물 특히 섬유소 분해균 및 메탄 생성균에 직간접으로 나쁜 영
향을 미치게 되어 반추위 발효기전을 변화시켜 대사장애를 가져올 수 있다(Chalupa 등, 1986; Ikwuegbu와 Sutton, 1982; Kowalczyk 등, 1977). 지방 첨가시 발생되는 유해한 영향을 방지할 수 있는 반추위내 각 영양소 대사에 대한 기전 및 지방 공급원의 형태에 대한 연구가 1970년 대부터 활발히 진행되어 왔다.

이 연구들의 목적은 첫째, 반추위 발효성상 과 소화에 유해한 영향 없이 반추동물에게 지

Corresponding author : T. Y. Chung, Department of Animal science, College of Animal Husbandry, Konkuk University, Gwangjin-gu, Seoul 143-701, Korea, Tel : 02-450-3673, Fax : 02-455-5305, E-mail : tychyng@kkucc.konkuk.ac.kr 
방을 첨가할 수 있도록 미생물에 미치는 지방 산의 부의 효과를 조정하는 것과 둘째, 특정 지방산이 흡수될 수 있도록 미생물에 의한 수 소첨가를 조절하여 고기와 우유내 포화도를 감 소시켜 품질을 개선하고 가축의 능력을 향상시 키는 것이다(Jenkins, 1993).

By-pass 지방에 대한 연구는 반추위 내에서 지방의 용해와 분해 및 수소첨가로부터 지방을 보호하여 반추위 소화 및 발효기전을 정상으로 유지하고 소장에서 지방분해효소인 lipase의 작 용효율을 높이는 것으로서(Palmquist, 1991), 여 기에는 포화지방산 형태, 칼슘염, formaldehyde 처리 등 여러 가지 방법이 있다(Grummer, 1988; Palmquist, 1991; Schauff와 Clark, 1989). 이러한 방법을 이용할 경우 반추위 소화 및 발효기전 을 정상으로 유지하면서 지방의 효율적인 이용 을 기대할 수 있다는 장점이 있다.

종실유 중에서 특히 아마유, 채종유, 해바라 기유, 대두유 및 옥수수유 등을 에너지원으로 사용할 수 있는 방법을 구명하기 위한 연구가 발표되었다(Beam 등, 2000; Doreau와 Chilliard, 1997; Ferlay 등, 1993; Fievez 등, 2003; Ikwuegbu와 Sutton, 1982; Sutton 등, 1983). 특히 이들 oil내에는 linoleic acid(LA, $\mathrm{C}_{18: 2}$ ) 및 linolenic acid(LNA, $\mathrm{C}_{18: 3)}$ 의 함량이 높아 반추위 내 에서 conjugated linoleic acid(CLA)의 생성을 촉 진시킬 수 있기 때문에 최근에 기능성 식품생 산을 위한 공급원으로 많은 연구가 진행되고 있다(Enser 등, 1999; Scolan 등, 2001; Wang 등, 2002). 그러나, oil은 불포화지방산 함량이 높 기 때문에 반추위 내에서 쉽게 노출되어 용해, 분해 및 수소가 첨가되어 반추위의 소화 및 발 효기전에 큰 영향을 미친다(Chalupa 등, 1986).

이와 같이 oil 첨가시 반추위에서 유리된 지 방산은 섬유소 소화를 억제하는 작용이 있지 만, 지방산 칼슘염은 이러한 억제작용이 없는 것으로 알려져 있다(Jenkins와 Palmquist, 1982). 또한 지방산 칼슘염은 착유우의 소화율을 거 의 정상 수준으로 유지할 수 있다(Jenkins와 Palmquist, 1984).

반추위 내에서 유리된 지방산이 양이온과 결 합하여 지방산염을 형성한 후, 조사료의 입자
는 미생물과 경합하여 지방산염을 물리적으로 흡착하여 섬유소 억제 반응을 감소시킬 수 있 으며, 지방산염을 흡착하는 정도는 조사료의 종류에 따라 다르다. 또한 알팔파는 화본과 및 저질 조사료에 비해 각각 2 및 3 배 정도 흡착 능력이 높았다고 보고하였다(Palmquist와 Yang, 1999; 김, 2004).

김 등(2004)은 알팔파 건초를 기질로 대두유 및 옥수수유를 $10 \%$ 첨가한 in vitro 시험 결과 배양시간이 증가할수록 oil을 첨가하지 않은 대 조구에 비해 지방산염의 형성이 높았다고 $(\mathrm{P}<$ $0.0001)$ 하였다. 이상의 in vitro 시험결과를 입 증하기 위하여 지방산 흡착량이 가장 높은 알 팔파건초에 대두유와 옥수수유를 첨가하여 면 양에게 급여할 때 반추위내 non-esterified fatty acid(NEFA), esterified fatty acid(EFA) 및 FAS 형성정도와, 반추위내 발효특성과 소화율에 미 치는 영향을 조사하기 위하여 본 연구를 실시 하였다.

\section{재료 및 방법}

\section{1. 시험설계}

면양 3두를 이용하여 1) oil 무첨가구, 2) 대 두유 $7 \%$ 첨가구 및 3) 옥수수유 $7 \%$ 첨가구로 하였고, oil은 사료의 중량 건물 기준으로 첨가 하여 $3 \times 3$ 라틴방각법으로 수행하였다.

\section{2. 공시동물}

공시동물은 건국대학교 축산대학 실험동물 사 육실에서 반추위에 cannula가 장착된 Corriedale $\times$ Suffolk 종 면양(평균체중 $52.17 \mathrm{~kg} \pm 2.02$ ) 3두를 이용하였다. 면양은 대사틀에 수용하여 적응하 였고, 사료는 1일 2회(09:00, 19:00) 급여하였으 며, 물 및 mineral block(Vitablock, Castyne Ltd., England)은 자유섭취 시켰다.

\section{3. 시험사료와 반추위액 채취}

면양에는 대사체중당 건물 $55 \mathrm{~g}$ 을 기준량으로 
하여 알팔파건초(1번초)와 농후사료(젓소 큰송 아지, 양주축협)를 $70: 30$ 의 비율로 급여하였다. 알팔파건초를 먼저 급여한 후 oil을 농후사료에 혼합하여 바로 급여하였다. 급여사료의 화학적 조성은 Table 1에 나타내었다. 반추위액은 오전 사료 급여 전 1 시간, 사료 급여 후 $1,3,6$ 및 9시간째 채취하였다.

\section{4. 반추위액 내용물 처리 및 측정항목}

(1) 반추위 발효성상

각각의 시간대별로 반추위액을 채취한 직후 $\mathrm{pH}$ 를 측정한 다음 곧 바로 실험실로 가져와서 상층액 분리를 위해서 $250 \mathrm{~mL}$ 원심분리용 tube 에 옮겨 $18,000 \times \mathrm{g}, 4^{\circ} \mathrm{C}$ 에서 30 분간 원심분리 (Supra 21K, Hanil Science Industrial Co., LTD.,

Table 1. Chemical and fatty acid composition of experimental diets

\begin{tabular}{|c|c|c|c|c|}
\hline Item & Alfalfa 1st cut & Concentrate & Soybean Oil & Corn Oil \\
\hline Dry matter(\%) & 91.47 & 89.92 & & \\
\hline \multicolumn{5}{|c|}{............ $\%$ of DM $\cdots \cdots \ldots \ldots \ldots$} \\
\hline Crude protein & 20.00 & 15.17 & & \\
\hline Ether extract & 2.78 & 3.06 & & \\
\hline Crude fiber & 42.72 & 5.09 & & \\
\hline Ash & 7.64 & 6.92 & & \\
\hline Calcium & 1.75 & 0.81 & & \\
\hline Potassium & 1.73 & 1.00 & & \\
\hline Magnesium & 0.32 & 0.34 & & \\
\hline Sodium & 0.46 & 0.46 & & \\
\hline Nitrogen free extract & 26.86 & 69.76 & & \\
\hline Neutral detergent fiber & 57.36 & 30.92 & & \\
\hline Acid detergent fiber & 49.09 & 9.34 & & \\
\hline \multicolumn{5}{|c|}{ Fatty acid composition, wt $\%$ of total fatty acid } \\
\hline $\mathrm{C}_{14: 0}$ & 3.63 & 0.36 & $\mathrm{ND}^{1)}$ & ND \\
\hline $\mathrm{C}_{16: 0}$ & 31.71 & 18.30 & 10.93 & 12.48 \\
\hline $\mathrm{C}_{16: \ln 7}$ & 0.51 & 0.34 & 0.09 & 0.15 \\
\hline $\mathrm{C}_{18: 0}$ & 6.52 & 1.94 & 4.13 & 2.05 \\
\hline $\mathrm{C}_{18: \ln 9}$ & 4.22 & 23.03 & 22.86 & 28.46 \\
\hline $\mathrm{C}_{18: 2 \mathrm{n} 6}$ & 16.19 & 48.60 & 53.25 & 55.03 \\
\hline $\mathrm{C}_{18: 3 \mathrm{n} 3}$ & 26.40 & 3.13 & 6.69 & 0.73 \\
\hline $\mathrm{C}_{20: 0}$ & 3.22 & 0.42 & 0.35 & 0.45 \\
\hline $\mathrm{C}_{20: 1 \mathrm{n} 9}$ & ND & ND & 0.28 & 0.33 \\
\hline $\mathrm{C}_{20: 5 \mathrm{n} 3}$ & ND & 0.41 & ND & ND \\
\hline $\mathrm{C}_{22: 0}$ & 3.22 & 1.49 & 0.38 & 0.15 \\
\hline $\mathrm{C}_{22: 1 \mathrm{n} 9}$ & ND & 1.49 & ND & ND \\
\hline Others $^{2)}$ & 4.96 & 1.24 & 1.04 & 0.17 \\
\hline Total & 100.00 & 100.00 & 100.00 & 100.00 \\
\hline
\end{tabular}

${ }^{1)} \mathrm{ND}$ : not detectable, ${ }^{2)}$ unknown fatty acid. 
Korea)하였다. 원심분리 후 상층액에 대해서는 $\mathrm{NH}_{3}-\mathrm{N}$ 및 $\mathrm{VFA}$ 를 측정하였다.

(2) 지방산 분획

지방산 분획을 위해서 반추위액 채취 후 내 용물을 $50 \mathrm{~mL}$ 원심분리용 tube에 옮겨 $35,000 \times$ g, $4{ }^{\circ} \mathrm{C}$ 에서 20 분간 원심분리(Supra $21 \mathrm{~K}$, Hanil Science Industrial Co., LTD., Korea)한 후 분석 하였다. 위의 원심분리 속도에서는 상층액 내 에 지방산이 거의 남지 않으므로 상층액은 제 거하였다(Jenkins와 Palmquist, 1982).

\section{5. 분석 항목}

\section{(1) 화학성분 분석}

시료와 분 및 뇨의 일반성분분석은 $\mathrm{AOAC}$ (1995) 방법에 준하여, NDF 및 $\mathrm{ADF}$ 는 Van Soest 등(1991)의 방법에 의해 분석하였다. $\mathrm{Ca}, \mathrm{K}, \mathrm{Mg}$ 및 $\mathrm{Na}$ 은 Automatic Absorption Spectrophotometer (Spectra AA 880, Varian, USA)를 이용하여 분 석하였다.

\section{(2) $\mathrm{pH}$ 측정}

반추위액은 각각의 시간대별(사료 급여전 1 시간, 사료급여 후 $1,3,6$ 및 9시간째)로 채취 직후 $\mathrm{pH}$ meter(pH 209, Hanna Instruments, Italy) 를 이용하여 측정하였다.

(3) $\mathrm{NH}_{3}-\mathrm{N}$ 측정

$\mathrm{NH}_{3}-\mathrm{N}$ 은 Chaney와 Marbach(1962) 방법에 따 라서 $12 \mathrm{~mL}$ 의 상층액을 원심분리하여 $0.02 \mathrm{~mL}$ 를 $20 \mathrm{~mL}$ 시험관에 넣고, phenol color reagent와 alkali-hypochlorite를 각각 $1 \mathrm{~mL}$ 를 첨가 후 혼합하 여 항온수조에서 발색반응 후 spectrophotometer (UV S-2100, Scinco Co., LTD., Korea)를 이용하 여 $630 \mathrm{~nm}$ 의 파장에서 표준 $\mathrm{NH}_{3}-\mathrm{N}$ 용액과 시료 의 흡광도를 측정하였다.

\section{(4) VFA 측정}

배양액중의 $\mathrm{VFA}$ 는 원심분리 후 상층액과 $25 \%$ metaphosphoric acid를 4:1비율로 혼합한 후 상층 액을 이용하여 GC(HP 6890 Series GC System,
Hewlett Packard, USA)로 분석하였고, VFA 표 준용액으로는 acetic과 propionic acid를 각각 $0.05 \mathrm{M}$, butyric, iso-butyric, valeric 및 iso-valeric acid는 각각 $0.01 \mathrm{M}$ 을 혼합하여 만든 용액을 사 용하여 표준용액의 면적과 비교하여 VFA의 생 성량을 측정하였다.

\section{(5) 지방산의 분획 및 지방산염 측정}

2시간동안 $80^{\circ} \mathrm{C}$ 에서 건조시킨 후 무게를 측 정하여 반추위액 내용물의 건물을 계산하였다 (Bateman과 Jenkins, 1998). Folch 용액(chloroform: methanol = 2:1, V/V, Folch 등, 1957)을 넣은 후 균질화하였다. 뚜껑을 닫은 후 $600 \times g$ 에서 10 분간 원심분리하여 추출물은 $250 \mathrm{~mL}$ separatory funnel로 옮겼다. 이 과정을 2번 더 반복하 여 $\mathrm{FAS}$ 를 제외한 $\mathrm{NEFA}$ 와 $\mathrm{EFA}$ 를 추출하였다. Folch 용액의 $1 / 4$ volume의 $0.9 \% \mathrm{NaCl}$ 용액을 첨가하여 잘 혼합한 후 정치시키면 수용액층과 유기용매층으로 분리된다. 유기용매층만 round flask에 분리하고 EYELA evaporator를 이용하여 유기용매를 제거하고 지질만을 분리하였다. Chloroform $5 \mathrm{~mL}$ 를 이용하여 round flask내의 지 질을 추출한 후 $1 \mathrm{~mL}$ 를 silicagel plates $(20 \mathrm{~cm} \times$ $20 \mathrm{~cm}$ Slicagel 60 F254, Merck Ltd.)에 주입한 후 thin layer chromatography 방법으로서 hexane:diethylether:acetic acid(80:30:1, v/v)을 넣은 수조에 넣어 전개 후 분획하였다.

원심분리용 tube에 남아있는 FAS는 2시간 동안 $80^{\circ} \mathrm{C}$ 에서 건조시킨 후 지방산 분석에 사용하였다. 3 가지 분획(NEFA, EFA 및 FAS)의 지방산 함량 및 조성을 분석하기 위하여 $1 \mathrm{mg}$ 의 nonadecanoic $\operatorname{acid}(\mathrm{C} 19: 0)$ 를 internal standard로 사용하여 onestep extraction and methylation 방법(Sukhija와 Palmquist, 1988)을 이용하여 GC (HP 6890 Series GC System, Hewlett Packard, PA, USA)로 분석하 였다. GC에는 FID(Flame Ionization Detector)가 장 착되어 있으며, 칼럼은 fused silica capillary column[Omegawax 320; 30m $\times 0.32 \mathrm{~mm}$ (i.d.) with 0.25 $\mu \mathrm{m}$ film thickness, Supelco Inc., Bellefonte, PA, USA]을 사용하였고, 질소를 carrier gas로 사용하 였다. Data는 Integrator(HP 3395; Hewlett Packard, $\mathrm{PA}, \mathrm{USA})$ 를 이용하여 산출하였다. 


\section{6. 통계분석}

본 시험에서 얻어진 모든 결과치는 GLM(general linear model)으로 SAS package program(2002, release, 8.e ver.)을 이용하여 분석하였다. 본 시 험의 통계분석 모델은 다음과 같다.

$$
\begin{aligned}
\mathrm{Y}_{\mathrm{ijkl}}= & \mu+\mathrm{F}_{\mathrm{i}}+\mathrm{T}_{\mathrm{j}}+\mathrm{O}_{\mathrm{k}}+\mathrm{F} \times \mathrm{T}_{\mathrm{ij}}+\mathrm{e}_{\mathrm{ijkl}} \\
\mu \quad= & \text { 시험전체 평균, } \\
\mathrm{F}_{\mathrm{i}} \quad & \text { 사료(oil 무첨가구, 대두유 } 7 \% \text { 첨가 } \\
& \text { 구, 옥수수유 } 7 \% \text { 첨가구)간의 평균효 } \\
& \text { 과 }(\mathrm{i}=1,2,3), \\
\mathrm{T}_{\mathrm{j}} & =\text { 시간의 평균효과 }(\mathrm{j}=1,2,3,4,5), \\
\mathrm{O}_{\mathrm{k}}= & \text { 대두유와 옥수수유간의 평균효과 }(\mathrm{k} \\
& =1,2), \\
\mathrm{F} \times \mathrm{T}_{\mathrm{ij}}= & \text { 사료와 시간의 상호작용의 평균효과, } \\
\mathrm{e}_{\mathrm{ijkl}}= & \text { 실험오차이다. }
\end{aligned}
$$

각 처리구의 평균치는 LSMean으로 보고하였 다. 각 처리구간 평균치간의 유의적 차이 검정 은 PDIFF 방식으로 실시하였으며, 유의성은 $\mathrm{P}<$ 0.05 일 때 유의적인 차이가 있었던 것으로 인 정하였다.

\section{III 결과 및 고찰}

\section{1. $\mathrm{pH}, \mathrm{NH}_{3}-\mathrm{N}$ 및 $\mathrm{VFA}$ 의 변화}

각 처리구간 반추위액의 $\mathrm{pH}, \mathrm{NH}_{3}-\mathrm{N}$ 및 $\mathrm{VFA}$ 의 변화는 Table 2에 나타내었다. $\mathrm{pH}$ 는 사료 급여후 3 시간까지 감소하다가 6시간 이후에 증 가하였으며 $(\mathrm{P}<0.0001)$, 처리구와 반추위액 채 취 시간간의 상호작용 및 oil간 차이는 없었다. Elliott 등(1993)은 비유초기 착유우에게 알팔파 와 농후사료를 $37: 63$ 으로 급여하고 옥수수유 와 우지의 첨가 비율을 증가시켜도 $\mathrm{pH}$ 에는 변 화가 없다고 보고하였다. Jenkins와 Fotouhi (1990)도 면양에게 Bermuda grass와 농후사료를 44:56으로 급여하고 옥수수유를 $2.4 \%$ 첨가했을 때 $\mathrm{pH}$ 에는 변화가 없었다고 발표하였다.

$\mathrm{NH}_{3}-\mathrm{N}$ 의 변화는 사료급여후 3시간까지 증가 하다가 그 이후 감소하였다 $(\mathrm{P}<0.0001)$. 사료급 여 1 시간전과 사료급여 후 1 시간까지는 대조구
가 높았으나, 3시간 이후에는 대두유 첨가구가 높았으며 $(\mathrm{P}<0.05)$, oil간 효과에서는 옥수수유 첨가구가 대두유 첨가구에 비해 낮았다 $(\mathrm{P}<$ 0.05). Elliott 등(1993)은 비유초기 착유우에게 알팔파 건초와 농후사료를 $37: 63$ 으로 급여하 고 옥수수유와 우지의 첨가 비율을 증가시켜도 $\mathrm{NH}_{3}-\mathrm{N}$ 는 변화가 없었다고 발표하였다. Bermuda grass와 농후사료를 50:50으로 급여하고 대두유 를 2, 4, 6 및 $8 \%$ 첨가했을 때 $4 \%$ 첨가구에서 $\mathrm{NH}_{3}-\mathrm{N}$ 가 가장 높았다고 보고하였다(Bateman 과 Jenkins, 1998).

총휘발성지방산, acetate(A), propionate(P) 및 butyrate의 변화는 처리구, 반추위액채취 시간, 처리구와 반추위액채취 시간간의 상호작용 및 oil간 효과는 없었다. iso-butyrate, valerate 및 iso-valerate는 사료급여 1 시간 전보다 사료급여 후 9시간까지 감소하였다 $(\mathrm{P}<0.0001)$.

$\mathrm{A} / \mathrm{P}$ 비율은 사료급여 후 낮아지다가 9시간에 는 사료급여전과 비슷한 수준으로 증가하였다 $(\mathrm{P}<0.0001)$. Jenkins와 Fotouhi(1990)는 면양에게 Bermuda grass와 농후사료를 $44: 56$ 으로 급여하 고 옥수수유를 $2.4 \%$ 첨가했을 때 $\mathrm{A} / \mathrm{P}$ 비율에는 변화가 없었다고 보고하여 본 실험과 비슷한 경향을 나타내었다. $\operatorname{Mir}(1988)$ 는 면양에게 분쇄 한 알팔파 건초를 급여하고 불포화지방산 비율 이 높은 채종유를 $10 \%$ 급여했을 때, 반추위내 $\mathrm{VFA}$ 는 아무런 변화가 없었다고 발표하였다. Zinn(1989)은 비육우에게 yellow grease와 동물 식물성 혼합 지방을 혼합하여 4 및 $8 \%$ 급여했 을 때 지방 첨가구가 무첨가구에 비해서 $\mathrm{A} / \mathrm{P}$ 비율이 낮았다고 보고하였다. Bermuda grass와 농후사료를 $50: 50$ 으로 급여하고 대두유를 2, 4, 6 및 $8 \%$ 를 첨가했을 때 $\mathrm{A} / \mathrm{P}$ 비율이 oil 첨 가구가 무첨가구에 비해서 낮았다 $(\mathrm{P}<0.05)$ 고 보고하였다(Bateman과 Jenkins, 1998).

일반적으로 oil을 5\% 이상 첨가하면 반추위 내 발효에 유해한 영향을 미칠 수 있으나 건초 함량을 증가시키면 유해작용을 감소시킬 수 있 다고 보고하였다(Jenkins, 1993). 본 실험에서 반 추위 발효특성에 변화가 없었던 것은 알팔파건 초를 $70 \%$ 급여하면서 oil을 첨가했기 때문인 것으로 사료된다. 
Kim et al. ; Formation of Fatty Acid Soaps in Sheep 


\section{2. 소화율}

각 처리구간 영양소의 소화율은 Table 3에 나 타내었다. 건물, total-N, 조섬유, 조회분, NFE, $\mathrm{NDF}$ 및 $\mathrm{ADF}$ 소화율 모두 처리구 및 oil간 효과 는 없었다. 단, 조지방 소화율은 대조구, 대두유 및 옥수수유 첨가구가 각각 $63.48,82.88$ 및 $82.37 \%$ 로 대조구에 비해 oil 첨가구가 유의적으 로 높았다 $(\mathrm{P}<0.01)$. 그러나 oil간 효과는 없었다.

착유우에게 포화와 불포화지방산 비율을 달 리하여 지방산을 급여했을 때 건물, 유기물, $\mathrm{NDF}, \mathrm{ADF}$, 에너지 및 지방산 소화율은 처리구 간 차이가 없었다고 보고하였다(Drackley 등, 1992). 착유우에게 $50 \%$ fescue hay를 급여하면, 채종유나 우지를 $10 \%$ 첨가해도 유기물의 소화 율에는 영향을 미치지 않았다(Doreau 등, 1991). Bermuda grass와 농후사료를 $50: 50$ 으로 급여하 고 대두유를 2, 4, 6 및 8\%를 첨가했을 때 건 물, 유기물, nitrogen 및 $\mathrm{NDF}$ 의 소화율에는 차 이가 없었다는 Bateman과 Jenkins(1998)의 결과 와 비슷한 경향을 나타내었다.

조사료 급여 비율이 높으면 반추위 내 기능 (주로 $\mathrm{pH}$ )을 정상적으로 유지하면서 지방이 흡 착할 수 있는 면적을 제공하여 지방 이용을 증 진시킬 수 있다. 지방과 목건초의 상호 보완은 에너지 섭취와 반추위 기능을 정상적으로 유지 시키는데 중요하며 목건초의 종류가 영향을 미
친다(Palmquist, 1987).

반추위 발효성상에 지방 첨가로 발생하는 유 해한 영향은 젖소보다 면양이나 비육우에서 더 크다. 그 이유로는 1) 섬유소의 소화율과 반추 위내 정체시간은 젖소가 면양이나 비육우보다 낮기 때문에 소화율의 저하로 인한 영향을 크 게 받지 않고(Palmquist와 Conrad, 1978), 2) 젖 소의 사료에는 광물질 함량이 높고, 특히 $\mathrm{Ca}$ 과 $\mathrm{Mg}$ 은 가수분해에 의해 유리된 지방산과 결합 하여 염을 형성하기 때문이다(Palmquist와 Jenkins, 1980). 시험에 사용한 알팔파 건초의 양이온 함량이 4.26\%(건물기준, Table 1)로 높 기 때문에 반추위 내에서 지방산염 형성비율이 높을 것으로 사료된다.

Devendra와 Lewis(1974)는 첨가한 지방이 사 료내 섬유소 표면을 물리적으로 coating하여 섬 유소 표면은 그 성질이 친수성(hydrophilic)에서 소수성으로 바뀌고, 반추위내 미생물이 섬유소 표면에 접촉할 수 있는 면적이 감소함으로써 섬 유소 소화율이 감소하였다고 보고하였다. 목건초 의 물리적인 구조와 표면적이 섬유소 소화에 미 치는 중요한 요소로 작용한다(Bowman과 Firkins, 1993; Mertens와 Loften, 1980). 알팔파건초는 다 른 목건초에 비해 가용성 함량이 높기 때문에 (Van Soest, 1994) 반추위 내에서 빠른 시간내에 분해되고 그 공극에 반추위 내에서 분해된 유리 지방산과 지방산염 중 많은 양이 흡착할 수 있

Table 3. Total tract digestibility of sheep fed soybean oil and corn oil

\begin{tabular}{lcccccc}
\hline \multirow{2}{*}{ Item } & \multirow{2}{*}{$\mathrm{C}^{1)}$} & $\mathrm{SBO}^{2)}$ & $\mathrm{CO}^{3)}$ & $\mathrm{SEM}^{4)}$ & \multicolumn{2}{c}{ Effects $^{5)}, \mathrm{P}<$} \\
\hline \hline Dry matter & 72.09 & 70.10 & 66.76 & 2.00 & 0.6122 & 0.6157 \\
Total-N & 26.96 & 24.73 & 28.01 & 3.79 & 0.9519 & 0.7746 \\
Ether Extract & 63.48 & 82.88 & 82.37 & 3.40 & 0.0016 & 0.8758 \\
Crude Fiber & 64.46 & 60.88 & 56.54 & 2.62 & 0.5284 & 0.6055 \\
Ash & 43.78 & 40.78 & 33.87 & 4.80 & 0.7448 & 0.6732 \\
NFE $^{6)}$ & 80.42 & 79.60 & 76.07 & 1.39 & 0.4577 & 0.4404 \\
NDF $^{7)}$ & 65.76 & 63.55 & 59.15 & 2.11 & 0.4890 & 0.5251 \\
$\mathrm{ADF}^{8)}$ & 65.76 & 63.58 & 59.57 & 2.10 & 0.5377 & 0.5571 \\
\hline
\end{tabular}

${ }^{1)} \mathrm{C}$ : control, ${ }^{2)} \mathrm{SBO}: 7 \%$ soybean oil, ${ }^{3)} \mathrm{CO}: 7 \%$ corn oil, ${ }^{4)} \mathrm{SEM}:$ standard error of the mean.

5) Effects were feed(F : between control, $7 \%$ soybean oil and $7 \%$ corn oil), between $7 \%$ soybean oil and $7 \%$ corn oil(O).

${ }^{6)} \mathrm{NFE}$ : nitrogen free extract, ${ }^{7)} \mathrm{NDF}$ : neutral detergent fiber, ${ }^{8)} \mathrm{ADF}$ : acid detergent fiber. 
었던 것으로 사료된다. 그래서 oil 첨가가 영양소 의 소화율에 영향을 미치지 않았다.

\section{3. 지방산 변화}

(1) 지방산 분획내 총 함량 변화

각 처리구간 시간별 지방산 분획내 총 함량 변화를 Table 4에 나타내었다.

FAS와 NEFA는 사료 급여전 1시간에 비하여 사료급여 후에 증가하였으며 $(\mathrm{P}<0.05)$, 대조구에 비해 oil 첨가구가 높았다 $(\mathrm{P}<0.01) . \mathrm{EFA}$ 는 사료 급여전 1 시간에 비하여 사료급여 후 1 시간에 높 았다가 3 시간 이후에 감소하였다 $(\mathrm{P}<0.001)$. 사료 급여후 1 시간에서 대두유 첨가구보다 옥수수유 첨가구가 높았다 $(\mathrm{P}<0.05)$.

Palmquist 등(1986)은 착유우를 이용하여 (1) 우 지 및 칼슘 무첨가, (2) 우지 $10 \%$ 첨가 및 칼슘 무첨가, (3) 우지 $10 \%$ 첨가 및 용해도가 낮은 칼 슘 첨가 및 (4) 우지 $10 \%$ 첨가 및 용해도가 높은 칼슘 첨가구로 나누어 시험한 결과 지방산염을 형성하는데 가장 중요한 요인은 반추위내 존재 하는 장쇄지방산의 농도라고 보고하였다. 또한 용해도가 낮은 $\mathrm{Ca}$ 첨가는 지방산염 형성을 증가 시키지 않았다고 하였다. 그리고 이온화된 $\mathrm{Ca}$ 의 농도는 반추위내 $\mathrm{pH}$ 와 부의 상관관계 $(\mathrm{r}=-0.404$, $\mathrm{P}<0.01$ )가 있으므로 지방산염의 지방산 비율은 $\mathrm{pH}$ 와 관계가 있다고 발표하였다.

알팔파건초와 옥수수 사일리지에 채종유 $7 \%$ 를 첨가했을 때, 액상물과 고형물의 하부장기 로의 전환율(turnover rate)은 각각 8.66 및 $11.79 \% / \mathrm{h}$ 로서 옥수수 사일리지 급여구에서 $40 \%$ 높았다 $(\mathrm{P}<0.05)$. 사료의 종류가 반추위내 사료입자의 통과속도를 변화시킨다고 보고하였 다(Salem 등, 1993). Bermuda grass와 농후사료 를 50:50으로 급여하고 대두유를 2, 4, 6 및 $8 \%$ 를 첨가했을 때 액상물 통과속도 $(\% / h)$ 가 최 소 10.30 에서 최대 10.74로 차이가 나타나지 않 았다. 결과적으로 oil 첨가는 액상물 통과속도 에 영향을 미치지 않았다고 발표하였다(Bateman과 Jenkins, 1998).

Allen(1996)은 ryegrass에 비해 알팔파는 반추 위 내에서 부양하는 시간이 더 짧기 때문에 전
환율이 증가하였다고 보고하였다. 전환율이 증 가하면 반추위내에서 형성된 FAS가 빠르게 하 부장기로 이전되어 FAS 형성 비율을 높이거나 미생물에 유해한 영향을 미치는 지방산을 빠르 게 제거할 수 있었다(Drackley 등, 1985).

목건초의 사료입자가 작아지면 비중(specific gravity)이 증가하게 되고, 반추위내 소화된 입 자의 비중은 1.3 에서 1.5 라고 하였다(SicilianoJones와 Murphy, 1991). 그래서 목건초의 종류를 달리함으로써 반추위내 비중을 변화시켜 소화된 사료입자가 반추위로부터 하부장기로의 전환율을 증가시키는데 도움을 줄 것이라고 하였다.

섬유소 표면에 금속 이온을 결합시키는 능력 을 양이온교환능력(cation exchange capacity)이 라고 하는데, $\mathrm{pH}$ 가 낮아졌을 때 해리된 $\mathrm{H}^{+}$이 온을 새로운 $\mathrm{K}^{+}, \mathrm{Ca}^{++}, \mathrm{Na}^{+}$그리고 $\mathrm{Mg}^{++}$이온으 로 교환하는 능력을 말한다. 성숙한 두과목초 는 가장 효율적인 양이온교환능력을 나타내는 목건초로서 그 능력은 옥수수 사일리지에 비해 3배정도 높은 것으로 알려져 있다(Van Soest 등, 1991).

섬유소 함량이 높으면 사료내 지질을 가수분 해 및 수소첨가 시키는 미생물의 성장이 빠르 게 촉진되고(Jenkins, 1993), 이때 생성된 NEFA 는 미생물 보다는 사료 입자에 더 잘 흡착된다 (Harfoot 등, 1974). 곡류에 비해 목건초의 cellulose 소화는 천천히 이루어지기 때문에 반추 위 내에 더 오래 정체하게 되고, 유리된 지방산을 잘 흡착시키고 빠르게 지방산염을 형성하여 섬유 소 소화에 미치는 유해한 영향을 방지할 수 있 게 된다(Bateman과 Jenkins, 1998).

본 시험에서 알팔파건초는 약 $6 \mathrm{~cm}$ 로 세절하 여 급여하였고, 조섬유 함량과 양이온 함량이 높다(Table 1). 첨가한 대두유와 옥수수유는 미 생물에 의해 가수분해되어 유리되며, NEFA는 양이온교환능력이 뛰어난 알팔파의 사료입자에 흡착된 후 양이온과 결합하여 지방산염을 형성 한다. 알팔파건초는 반추위로부터 하부장기로 의 통과속도가 다른 목건초에 비해 빠르기 때 문에 반추위 내에서 $\mathrm{pH}$ 의 변화에 의한 지방산 과 양이온이 해리없이 소화 및 흡수될 수 있었 다. 
Kim et al. ; Formation of Fatty Acid Soaps in Sheep 
(2) EFA와 NEFA 및 FAS의 지방산 조성의 변화

각 처리구간 $\mathrm{EFA}, \mathrm{NEFA}$ 및 FAS의 지방산 조성 변화를 Table 5와 Fig. 1에 나타내었다. $\mathrm{EFA}$ 의 $\mathrm{C}_{16: 0}, c i s-\mathrm{C}_{18: 1}$ 및 $\mathrm{C}_{18: 2}$ 는 배양시간이 증 가함에 따라 감소하였다 $(\mathrm{P}<0.0001)$. 처리구 및 처리구와 배양시간의 상호작용 효과도 차이를 보였다 $(\mathrm{P}<0.001) . \mathrm{C}_{16: 0}$ 과 cis- $\mathrm{C}_{18: 1}$ 은 oil간 효과 도 차이를 보였다 $(\mathrm{P}<0.05)$. 모든 지방산이 사 료 급여 후 증가하였다가 배양시간이 증가함에 따라 감소하는 경향을 보여주었다. 김 등(2004) 이 같은 시료를 각각 $10 \%$ 씩 첨가한 in vitro 실 험에서도 $\mathrm{C}_{16: 0}, \mathrm{C}_{18: 0,}$ cis- $\mathrm{C}_{18: 1}$ 및 $\mathrm{C}_{18: 2}$ 는 배양시 간이 증가함에 따라 감소하였으며, 처리구 및 처리구와 배양시간의 상호작용도 차이를 나타 내었다 $(\mathrm{P}<0.0001)$.

$\mathrm{NEFA}$ 의 $\mathrm{C}_{16: 0}$ 은 사료 급여 후 증가하였고 $(\mathrm{P}<$ $0.01)$, 대조구에 비해 oil 첨가구가 높았다 $(\mathrm{P}<$ 0.0001). $\mathrm{C}_{18: 0}$ 은 사료 급여전 1시간보다 사료급 여 후 1 시간에는 감소하였지만 3 시간 이후에는 증가하였고 $(\mathrm{P}<0.0001)$, oil 첨가구가 대조구에 비해 높았다 $(\mathrm{P}<0.0001)$. trans $-\mathrm{C}_{18: 1}$ 은 사료급여 후 3시간에 가장 높았다가 그 이후 감소하였으 며 $(\mathrm{P}<0.0001)$, 대조구에 비해 oil 첨가구가 높 았다 $(\mathrm{P}<0.0001) . \mathrm{C}_{18: 2}$ 는 사료 급여 후 1 시간에 가장 높았다가 감소하였고 $(\mathrm{P}<0.01)$, oil 첨가구 가 대조구에 비해 높았다 $(\mathrm{P}<0.01)$. 김 등 $(2004)$ 의 in vitro 실험결과는 $\mathrm{C}_{16: 0}$ 과 $\mathrm{C}_{18: 0}$ 은 배양시간 이 경과함에 따라 증가하였고, oil 첨가구가 무 첨가구에 비해 NEFA 생성량이 높았다. $\mathrm{C}_{18: 1 \text {, }}$ $\mathrm{C}_{18: 2}$ 및 $\mathrm{C}_{18: 3}$ 은 배양초기에는 증가하다가 후기 에는 크게 감소하였다는 결과와 유사한 경향을 나타내었다. $\mathrm{C}_{16: 0}$ 과 $\mathrm{C}_{18: 0}$ 의 증가는 $\mathrm{EFA}$ 가 반추 위 내에서 반추위 미생물에 의해 가수분해 후 유리된 불포화지방산에 대한 수소첨가의 최종 산물이라 보고하였다(Palmquist와 Jenkins, 1980). 불포화지방산중 $\mathrm{C}_{18: 2}$ 와 $\mathrm{C}_{18: 3}$ 은 반추위내 미생물 에 의해 $\mathrm{C}_{18: 0}$ 또는 trans형태의 지방산으로 변 형되어 그 함량이 감소한 것으로 판단된다.

Moore 등(1969)은 면양에게 cannula를 통하여 옥수수유를 주입하였을 때 주입후 $1,2,3,4$, 6,8 및 24시간째의 $\mathrm{EFA}$ 와 NEFA의 변화를 시
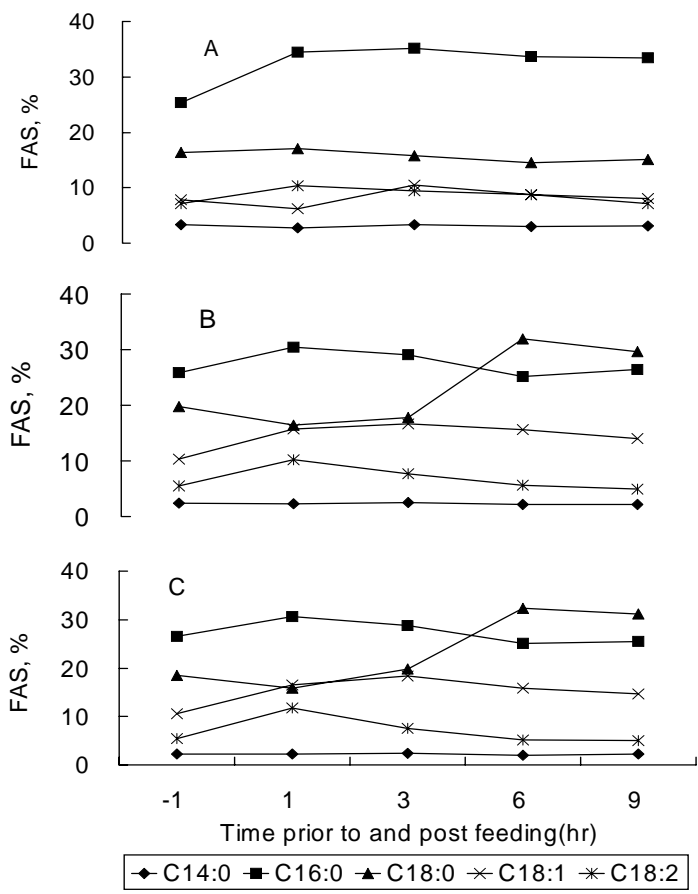

Fig. 1. Proportion of the reactive fatty acids pool forming fatty acid soap(FAS) vs sampling time in sheep.

Substrates: A) basal; B) basal $+7 \%$ soybean oil; C) basal $+7 \%$ corn oil.

험하였다. 그 결과 $\mathrm{EFA}$ 와 $\mathrm{NEFA}$ 모두 $\mathrm{C}_{16: 0}$, $\mathrm{C}_{18: 0}$ 은 증가하였고, $\mathrm{C}_{18: 1}$ 은 시간이 경과함에 따라 서서히 증가하다가 8시간에서 감소하기 시작하였고 $\mathrm{C}_{18: 2}$ 는 2 시간부터 감소하기 시작하 였다고 보고하였다. 또한 옥수수유 형태로 급 여하여 유리된 LA는 $\mathrm{C}_{18: 0}$ 으로 수소첨가 되지 만, NEFA형태인 LA를 반추위에 주입했을 경우 에는 $\mathrm{C}_{18: 0}$ 은 적게 생성되고 중간대사 물질인 $\mathrm{C}_{18: 1}$ 계열의 지방산이 축적된다고 보고하였다. 면양 반추위에 LA를 주입하였을 때, 주입 전에 는 $\mathrm{C}_{18: 0}, \quad$ cis- $\mathrm{C}_{18: 1}$, trans $-\mathrm{C}_{18: 1}$ 및 $\mathrm{C}_{18: 2}$ 가 각각 74.2, 2.6, 6.0 및 $0.5 \%$ 였지만 주입 후에는 각각 $41.7,7.5,36.6$ 및 5.0\%로 조성이 변했다고 보 고하였다(Noble 등, 1974).

지방분해는 $\mathrm{pH}$ 가 6.0 이하일 때 낮아지고, 그 억제효과는 $\mathrm{pH}$ 감소와 밀접한 관계가 있으며, 수소첨가에 비해 지방분해가 $\mathrm{pH}$ 에 더 민감하 게 반응한다고 발표하였다(Van Nevel과 Demeyer, 
Kim et al. ; Formation of Fatty Acid Soaps in Sheep 
Kim et al. ; Formation of Fatty Acid Soaps in Sheep 
1996). 본 시험에서 반추위액 채취 시간 모두 $\mathrm{pH}$ 에 대한 처리구, 시간, 처리구와 시간의 상 호작용 및 oil간 효과가 유의적인 차이가 없었 고, 최저 $\mathrm{pH}$ 가 6.0 이상이었다. oil을 $7 \%$ 첨가한 구의 지방산 조성 변화는 oil을 고수준으로 첨 가하여 발생한 변화라고 사료된다.

본 시험에서는 알팔파 건초와 농후사료를 70 : 30으로 급여하여 조사료 급여비율이 높았다. 또한 알팔파는 다른 조사료에 비해 지방산염을 가장 많이 흡착할 수 있는 능력을 가지고 있고 (Palmquist와 Yang, 1999; 김, 2004), oil을 첨가 하면 사료급여후 3시간부터 지방산염 형성이 증가하였기 때문에(Table 4) oil 첨가로 인해 발 생하는 발효성상에 미치는 부의 영향이 없었던 것으로 사료된다.

시료내 EFA와 첨가한 대두유와 옥수수유가 배양시간이 증가함에 따라 반추위 미생물에 의 한 가수분해 작용으로 NEFA로 유리되고, $\mathrm{NEFA}$ 는 시료에서 용해된 양이온 및 배양액내 에 존재하는 양이온과 결합하여 지방산염을 형 성하였다(Jenkins와 Palmquist, 1982).

$\mathrm{FAS}$ 의 지방산 조성 변화를 살펴보면, $\mathrm{C}_{16: 0}$ 은 사료급여전 1 시간보다 사료급여 후에는 증가하 였으나 $(\mathrm{P}<0.01)$, 처리구, 처리구와 시간의 상호 작용 및 oil간 효과는 없었다. $\mathrm{C}_{18: 0}$ 은 사료급여 후 6시간에서 가장 높았고, 대조구에 비해서는 oil 처리구가 높았고 $(\mathrm{P}<0.05)$ 대두유 첨가구보 다 옥수수유 첨가구가 높았다 $(\mathrm{P}<0.05) . \quad$ cis- $\mathrm{C}_{18: 1}$ 은 사료급여전 1 시간에 비해서 사료급여 후 증 가하다가 6시간 이후에 감소하였다 $(\mathrm{P}<0.0001)$. 대조구에 비해서는 oil 처리구가 높았고 $(\mathrm{P}<$ 0.001) 대두유 첨가구보다 옥수수유 첨가구가 높았다 $(\mathrm{P}<0.05)$. trans- $\mathrm{C}_{18: 1}$ 은 사료급여전 1 시간 에 비해서 사료급여 후 증가하다가 6시간에 가 장 높았으며 9시간에 다시 감소하는 경향을 보 였다. 대조구에 비해서는 oil 처리구가 높았다(P $<0.05) . \mathrm{C}_{18: 2}$ 와 $\mathrm{C}_{18: 3}$ 은 사료급여 전에 비하여 사료급여 후에 증가하였지만 $(\mathrm{P}<0.0001)$, 처리 구, 처리구와 시간의 상호작용 및 oil간 효과는 없었다.

김 등(2004)의 in vitro 시험결과 FAS내 $\mathrm{C}_{18: 0}$ 은 oil 첨가구에서 높았고 대두유 첨가구보다
옥수수유 첨가구가 높았다. $\mathrm{C}_{18: 1}$ 은 6시간 배양 후 감소하였고 oil 첨가구가 미첨가구에 비해 높았으며, cis 보다는 trans형이 더 쉽게 지방산 염을 형성하였다는 보고와 본 시험결과는 일치 하였다. 그러나 $\mathrm{C}_{18: 2}$ 와 $\mathrm{C}_{18: 3}$ 의 in vitro 배양시간 별 변화는 본 실험 결과보다는 크지 않았다. 또한 배양시간 48시간에서 포화지방산이 불포 화지방산보다 더 많은 지방산염을 형성하였다 고 밝혀졌다. 본 시험에서도 $\mathrm{FAS}$ 형성이 가장 높았던 6 시간의 포화지방산 $\left(\mathrm{C}_{16: 0}\right.$ 과 $\left.\mathrm{C}_{18: 0}\right)$ 의 함 량(wt \%)은 대조구, 대두유 및 옥수수유 첨가 구에서 각각 67.99, 71.25 및 $72.77 \%$ 였고, 불포 화지방산 $\left(\mathrm{C}_{18: 1,}, \mathrm{C}_{18: 2} \quad\right.$ 및 $\left.\mathrm{C}_{18: 3}\right)$ 은 각각 32.01 , 28.75 및 27.23\%로 나타나 유사한 경향을 나타 내었다. 그러나 포화지방산의 비율이 낮은 것 은 반추위액 채취시간이 짧았던 까닭이라고 본 다.

결론적으로 대두유와 옥수수유를 $7 \%$ 첨가하 였을 때 사료급여 후 3시간부터 반추위 내에서 oil 첨가구가 대조구에 비해 지방산염이 많이 형성되었다. 이때 포화지방산이 불포화지방산 보다 지방산염을 더 잘 형성하였으며, $\mathrm{C}_{16: 0}$ 이 상의 장쇄지방산이 주로 지방산염을 형성하였 다. 또한 다른 목건초에 비해 반추위로부터 하 부장기로의 통과속도가 알팔파건초가 빠르기 때문에 반추위 내에서 $\mathrm{pH}$ 의 변화에 의한 지방 산과 양이온이 해리되지 않고 소화 및 흡수될 수 있을 것이다. 그러므로 oil이 반추위에 미치 는 유해한 영향을 방지할 수 있을 것으로 사료 된다.

실제 사양조건에서는 알팔파건초 뿐만 아니 라 화본과 및 저질 조사료도 급여하고 있는 실 정이기 때문에, 화본과와 저질 조사료에 대한 시험을 수행한 후 종합적인 고찰을 통하여 목 건초 종류별 oil의 적정 첨가수준을 결정해야 할 것이다.

\section{IV 요 약}

본 시험은 oil 첨가시 알팔파건초를 기질로 하여 반추위 내에서 유리된 지방산과 양이온이 결합하여 형성되는 지방산염, 반추위 발효성상 
및 소화율에 미치는 영향에 대하여 살펴보고자 시험을 실시하였다. 면양 3 두를 이용하여 (1) oil 무첨가구, (2) 대두유 7\% 첨가구 및 (3) 옥수 수유 $7 \%$ 첨가구로 하여 $3 \times 3$ 라틴방각법으로 수행하였다. 면양에게는 알팔파건초와 농후사 료를 70:30의 비율로 급여하였다. 위액은 오전 사료 급여 전 1 시간, 사료 급여 후 $1,3,6$ 및 9시간째 채취하였다.

$\mathrm{pH}$ 는 사료급여 후 3 시간까지 감소하다가 그 이후에는 증가하였다 $(\mathrm{P}<0.0001) . \quad \mathrm{NH}_{3}-\mathrm{N}$ 는 $\mathrm{pH}$ 와는 반대의 경향을 나타내었다 $(\mathrm{P}<0.0001)$. 총 휘발성 지방산, acetate, propionate 및 butyrate의 농도에는 변화가 없었다. $\mathrm{A} / \mathrm{P}$ 비율은 배양시간 이 증가함에 따라 감소하다가 9시간에서는 사 료급여 1 시간 수준이었다 $(\mathrm{P}<0.0001)$. 건물, total-N, 조섬유, 회분, 가용무질소물, $\mathrm{NDF}$ 및 $\mathrm{ADF}$ 의 소화율은 차이가 없었다.

$\mathrm{FAS}$ 의 형성은 사료급여 전 1 시간에 비하여 사료급여 후에 증가하였으며 $(\mathrm{P}<0.05)$, 대조구 에 비해 oil 첨가구가 높았다 $(\mathrm{P}<0.05)$. 장쇄지 방산이 주로 지방산염을 형성하였다. 그래서 oil 첨가가 반추위 발효특성과 소화율에 미치는 유해한 영향을 방지할 수 있었던 것으로 사료 된다.

\section{$\mathrm{V}$ 인 용 문 헌}

1. Allen, M. S. 1996. Physical constraints on voluntary intake of forage by ruminants. J. Anim. Sci., 74:3063-3075.

2. AOAC. 1995. Official Methods of Analysis (15th ed.). Association of Official Analytical Chemists, Washington, D. C.

3. Bateman, II, H. G. and Jenkins, T. C. 1998. Influence of soybean oil in high fiber diets fed to nonlactaing cows on ruminal unsaturated fatty aicds and nutrient digestibility. J. Dairy Sci., 81:2451-458.

4. Beam, T. M., Jenkins, T. C., Moate, P. J., Kohn, R. A. and Palmquist, D. L. 2000. Effects of amount and source of fat on the rates of lipolysis and biohydrogenation of fatty acids in ruminal contents. J. Dairy Sci., 83:2564- 2573.

5. Bowman, J. G. P. and Firkins, J. L. 1993. Effects of forage species and particle size on bacterial cel- lulolytic activity and colonization in situ. J. Anim. Sci., 71:1623-1633.

6. Chalupa, W., Vecchiarelli, B., Elser, A. E., Kronfeld, D. S., Sklan, D. and Palmquist, D. L. 1986. Ruminal fermentation in vivo as influenced by long-chain fatty acids. J. Dairy Sci., 69:1293-1301.

7. Chaney, A. L. and Marbach, E. P. 1962. Modified reagents for determination of urea and ammonia. Clinical Chemistry, 8:130-132.

8. Devendra, C. and Lewis, D. 1974. The interaction between dietary lipids and fibre in the sheep. Anim. Prod., 19:67-76.

9. Doreau, M. and Chilliard, Y. 1997. Effects of ruminal or postruminal fish oil supplementation on intake and digestion in dairy cows. Reprod. Nutr. Dev., 37:113-124.

10. Doreau, M., Legay, F. and Bauchart, D. 1991. Effect of source and level of supplemental fat on total and ruminal organic matter and nitrogen digestion in dairy cows. J. Dairy Sci., 74:2233-2242.

11. Drackley, J. K., Clark, A. K. and Sahlu, T. 1985. Rations digestibilities and ruminal characteristics in steers fed sunflower seeds with additional calcium. J. Dairy Sci., 68:356-367.

12. Drackley, J. K., Klusmeyer, T. H., Trusk, A. M. and Clark, J. H. 1992. Infusion of long-chain fatty acids varying in saturation and chain length into the abomasum of lactating dairy cows. J. Dairy Sci., 75:1517-1526.

13. Elliott, J. P., Drackley, J. K., Schauff, D. J. and Jaster, E. H. 1993. Diets containing high oil corn and talow for dairy cows during early lactation. J. Dairy Sci., 76:775-789.

14. Enser, M., Scollan, N. D., Choi, N. J., Kurt, E., Hallett, K. and Wood, J. D. 1999. Effect of dietary lipid on the content of conjugated linoleic acid (CLA) in beef muscle. Br. J. Anim. Sci., 69:143-146.

15. Ferlay, A., Chabrot, J., Elmeddah, Y. and Doreau, M. 1993. Ruminal lipid balance and intestinal digestion by dairy cows fed calcium salts of rapeseed oil fatty acids or rapeseed oil. J. Anim. Sci., 71:2237-2245.

16. Fievez, V., Dohme, F., Danneels, M., Raes, K. and Demeyer, D. 2003. Fish oils as potent rumen methane inhibitors and associated effects on rumen fermentation in vitro and in vivo. Anim. Feed Sci. Technol., 104:41-58.

17. Folch, J., Lees, M. and Sloane-Stanley, G. H. 1957. A simple method for the isolation and purification of total lipids from animal tissue. J. Biol. 
Chem., 226:497-509.

18. Grummer, R. R. 1988. Influence of prilled fat and calcium salt of palm oil fatty acids on ruminal fermentation and nutrient digestibility. J. Dairy Sci., 71:117-123.

19. Harfoot, C. G., Crouchman, M. L., Noble, R. C. and Moore, J. H. 1974. Competition between food particles and rumen bacteria in the uptake of long-chain fatty acids and triglycerides. J. Appl. Bact., 37:633-641.

20. Ikwuegbu, O. A. and Sutton, J. D. 1982. The effect of varying the amount of linseed oil supplementation on rumen metabolism in sheep. Br. J. Nutr., 48:365-375.

21. Jenkins, T. C. 1993. Lipid metabolism in the rumen. J. Dairy Sci., 76:3851-3863.

22. Jenkins, T. C. and Fotouhi, N. 1990. Effects of lecithin and corn oil in site of digestion, ruminal fermentation and microbial protein synthesis in sheep. J. Anim. Sci., 68:460-466.

23. Jenkins, T. C. and Palmquist, D. L. 1982. Effect of added fat and calcium on in vitro formation of insoluble fatty acid soaps and cell wall digestibility. J. Anim. Sci., 55:957-963.

24. Jenkins, T. C. and Palmquist, D. L. 1984. Effect of fatty acids or calcium soaps on rumen and total nutrient digestibility of dairy rations. J. Dairy Sci., 67:978-986.

25. Kowalczyk, J., Ørskov, E. R., Robinson, J. J. and Stewart, C. S. 1977. Effect of fat supplementation on voluntary food intake and rumen metabolism in sheep. Br. J. Nutr., 37:251-257.

26. Mertens, D. R. and Loften, J. R. 1980. The effect of starch on forage fiber digestion kinetics in vitro. J. Dairy Sci., 63:1437-1446.

27. Mir, Z. 1988. A comparison of canola acidulated fatty acids and tallow as supplements to a ground alfalfa diet for sheep. Can. J. Anim. Sci., 68:761-767.

28. Moore, J. H., Noble, R. C., Steele, W. and Czerkawski, J. W. 1969. Differences in the metabolism of esterified and unesterified linoleic acid by rumen micro-organisms. Br. J. Nutr., 23:869-878.

29. Noble, R. C., Moore, J. H. and Harfoot, C. G. 1974. Observations on the pattern on biohydrogenation of esterified and unesterified linoliec acid in the rumen. Br. J. Nutr., 31:99-108.

30. Palmquist, D. L. 1987. Adding fat to dairy diets. Animal Health \& Nutrition, pp. 32-35.

31. Palmquist, D. L. 1991. Influence of source and amount of dietary fat on digestibility in lactating cows. J. Dairy Sci., 74:1354-1360.

32. Palmquist, D. L. and Conrad, H. R. 1978. High fat rations for dairy cows. Effects on feed intake, milk and fat production, and plasma metabolites. J. Dairy Sci., 61:890-901.

33. Palmquist, D. L. and Jenkins, T. C. 1980. Fat in lactation rations: Review. J. Dairy Sci., 63:1-14.

34. Palmquist, D. L., Jenkins, T. C. and Joyner, Jr. A. E. 1986. Effect of dietary fat and calcium source on insoluble soap formation in the rumen. J. Dairy Sci., 69:1020-1025.

35. Palmquist, D. L. and Yang, U. M. 1999. Adsorption of fatty aicds to plant surfaces. S. Afr. J. Anim. Sci. 29(ISRP):59-60.

36. Salem, H. B., Krezeminski, R., Ferlay, A. and Doreau, M. 1993. Effect of lipid supply on in vivo digestion in cows: Comparison of hay and corn silage diets. Can. J. Anim. Sci., 73:547-557.

37. SAS. 2002. SAS User's Guide. Statistics, Version 8.e, SAS Institute. Inc., Cary, NC.

38. Schauff, D. J. and Clark, J. H. 1989. Effects of prilled fatty acids and calcium salts of fatty acids on rumen fermentation, nutrient digestibilities, milk production, and milk composition. J. Dairy Sci., 72:917-927.

39. Scollan, N. D., Dhanoa, M. S., Choi, N. J., Maeng, W. J., Enser, M. and Wood, J. D. 2001. Biohydrogenation and digestion of long chain fatty acids in steer fed on different sources of lipid. J. Agric. Sci., Camb., 136:345-355.

40. Siciliano-Jones, J. and Murphy, M. R. 1991. Specific gravity of various feedstuffs as affected by particle size and in vitro fermentation. J. Dairy Sci., 74:896-901.

41. Sukhija, S. and Palmquist, D. L. 1988. Rapid method for determination of total fatty acid composition of feedstuffs and feces. J. Agric. Food Chem., 36:1202-1206.

42. Sutton, J. D., Knight, R., McAllan, A. B. and Smith, R. H. 1983. Digestion and synthesis in the rumen of sheep given diets supplemented with free and protected oils. Br. J. Nutr., 49:419-432.

43. Tamminga, S. and Doreau, M. 1991. Lipids and rumen digestion. In: Rumen Microbial Metabolism and Ruminant Digestion (J. P. Jouany ed.). INRA, Paris. pp. 151-163.

44. Van Nevel, C. J. and Demeyer, D. I. 1996. Influence of $\mathrm{pH}$ on lipolysis and biohydrogenation of soybean oil by rumen contents in vitro. Reprod. Nutr. Dev., 36:53-63. 
45. Van Soest, P. J. 1994. Nutritional Ecology of the Ruminant.(2nd ed.) Cornell University Press, New York, USA.

46. Van Soest, P. J., Robertson, J. B. and Lewis, B. A. 1991. Methods for dietary fiber, neutral detergent fiber, and nonstarch polysaccharides in relation to animal nutrition. Symposium: Carbohydrate methodology, metabolism, and nutritional implications in dairy cattle. J. Dairy Sci., 74:3583-3597.

47. Wang, J. H., Song, M. K., Son, Y. S. and Chang, M. B. 2002. Addition effect of seed-associated or free linseed oil on the formation of cis-9, trans-11 conjugated linoleic acid and octadecenoic acid by ruminal bacteria in vitro. Asian-Aus. J. Anim. Sci., 15:1115-1120.
48. Zinn, R. A. 1989. Influence of level and source of dietary fat on its comparative feeding value in finishing diets for feedlot steers: Metabolism. J. Anim. Sci., 67:1038-1049.

49. 김동일. 2004. 식물성유 첨가가 반추위내 지방산 조성, 지방산염 형성 및 $\mathrm{NDF}$ 소화율에 미치는 영향. 건국대학교 박사학위논문.

50. 김동일, 최정락, 이윤행, 이정권, 정태영. 2004. 식물성유 첨가가 in vitro 발효성상, $\mathrm{NDF}$ 소실율 및 지방산염 형성에 미치는 영향. 동물자원과학 회지. 46(3):355-372.

(접수일자 : 2004. 7. 7. / 채택일자 : 2004. 10. 20.) 